\title{
POLA KOMUNIKASI SUAMI-ISTRI DALAM TEKANAN PASCA MELAHIRKAN DI KOTA BANDAR LAMPUNG
}

\author{
Kinantri Puspa Sari ${ }^{1^{*}}$, Maulana Rezi Ramadhana ${ }^{1}$ \\ ${ }^{1}$ Program Studi IImu Komunikasi, Universitas Telkom, Bandung 40257, Indonesia \\ *)E-mail: kinantrips@gmail.com
}

\begin{abstract}
Abstrak
Periode pasca melahirkan adalah periode transisi yang dialami oleh pasangan suami istri yang membutuhkan upaya penyesuaian terhadap hadirnya perubahan dalam hubungan relasi, terlebih saat pihak istri yang mengalami tekanan (depresi) pasca melahirkan selama periode tersebut. Periode pasca melahirkan menimbulkan perubahan kondisi yang diikuti dengan berubahnya peran dan tanggung jawab, yang dapat mempengaruhi hubungan komunikasi di antara pasangan. Penelitian ini berfokus pada pola komunikasi suami-istri dalam tekanan pasca melahirkan dengan menggunakan pendekatan Teori Pola Komunikasi Interpersonal yang didukung oleh Teori Turbulansi Relasi. Metode penelitian yang digunakan adalah metode kualitatif dengan teknik pengambilan data berupa wawancara terhadap empat pasangan suami dan istri yang berdomisili di Kota Bandar Lampung, penetapan informan didapat melalui strategi snowball sampling (metode multitahapan) dengan informan ahli sebagai konfirmasi data. Hasil menunjukkan bahwa seluruh pasangan memiliki pola komunikasi seimbang terpisah (balanced split pattern) selama menghadapi tekanan pasca melahirkan, yang ditandai dengan adanya pembagian tanggung jawab pada peran yang berbeda. Dalam pola komunikasi seimbang terpisah, seluruh informan mengalami hambatan juga dukungan komunikasi, dan sebagian mengalami ketidakpastian hubungan, sementara strategi konstruktif digunakan sebagai pendekatan dalam strategi manajemen konflik di antara pasangan, ditandai dengan adanya keterbukaan komunikasi dan negosiasi. Konflik terkait dengan tugas pengasuhan anak dan kurangnya kualitas interaksi menjadi temuan dalam penelitian ini.
\end{abstract}

Kata kunci: pola komunikasi, depresi pasca melahirkan, pasangan

\section{Communication Pattern of Married Couples in Postpartum Depression in Bandar Lampung}

\begin{abstract}
The postpartum period is a transitional period experienced by married couples who require adjustments to the presence of changes in their relationship, especially when the wife is experiencing postpartum stress (depression) during that period. The postpartum period causes changes in conditions followed by changing roles and responsibilities, which can affect the communication relationship between partners. This study focuses on communication patterns of married couples in postpartum pressure using the Interpersonal Communication Patterns Theory approach which is supported by the theory of relationship turbulence. The research method used is a qualitative method with data collection techniques in the form of interviews with four husband and wife couples who live in the city of Bandar Lampung, the determination of the informants is obtained through a snowball sampling strategy (multistage method) with expert informants as data confirmation. The results show that all couples have a separate balanced communication pattern (balanced split pattern) during the face of postpartum stress, which is marked by the division of responsibilities in different roles. In a balanced split communication pattern, all informants experience interferences as well as communication supports, and some experience relationship uncertainty, while constructive strategies are used as approaches in conflict management strategies between partners, characterized by open communication and negotiation. Conflicts related to childcare tasks and lack of quality interactions were the findings of this study.
\end{abstract}

Keywords: communication patterns; postpartum depression; couples 


\section{PENDAHULUAN}

Komunikasi merupakan faktor yang paling utama bagi kehidupan sosial sebagai manusia, yang salah satu jenisnya adalah komunikasi interpersonal. komunikasi interpersonal adalah interaksi verbal maupun nonverbal yang dilakukan oleh dua orang yang saling bergantung satu dengan yang lainnya (interdependent people), dengan kata lain, komunikasi ini terjadi antara orang-orang yang saling terkait, di mana di antara mereka saling memengaruhi satu sama lain, layaknya hubungan pada pasangan suami dan istri (Liliweri, 2015). Komunikasi dinilai sangat penting dalam upaya terjalinnya sebuah hubungan pada konteks pasangan. Keharmonisan dalam sebuah hubungan relasi berhubungan dengan komunikasi antarpersonal yang terjalin pada pasangan suami istri (Dewi and Sudhana, 2013). Kesejahteraan dan keharmonisan hubungan keluarga dipengaruhi oleh pola komunikasi yang digunakan pada keluarga tersebut (Muladsih, Muflikhati, and Herawati, 2011). Selain itu, upaya untuk menjaga keefektifan komunikasi dapat mengurangi munculnya konflik yang menghadirkan persoalan dalam hubungan pasangan. Salah satunya persoalan yang muncul pada hubungan sebagian pasangan adalah munculnya depresi pasca melahirkan yang terjadi pada ibu setelah kelahiran seorang anak. Dalam periode ini, pasangan suami istri tentunya dihadapkan pada berbagai perubahan dalam menghadapai kondisi baru. Hal ini yang membuat penelitian terhadap pola komunikasi pasangan suami-istri dalam menghadapi depresi pasca melahirkan menjadi penting untuk diteliti.

Depresi pasca melahirkan merupakan depresi yang dialami ibu setelah melahirkan dengan bentuk gejala berupa gangguan emosi, seperti sering menangis, murung, panik, mudah marah (Atmadibrata, 2005). Temuan lain dari menyebutkan bahwa terdapat tiga bentuk perubahan sisi psikologis pada ibu pasca melahirkan, meliputi postpartum blues (baby blues syndrom), postpartum depression dan postpartum psikosis (Yusari and Risneni, 2016). Penelitian ini juga didukung dengan penelitian yang dilakukan di Lampung memperlihatkan bahwa dari 111 ibu postpartum, didapatkan 59 orang ibu $(53,15 \%)$ yang mengalami kejadian depresi post partum. Berdasarkan hasil tersebut, 59 orang ibu postpartum yang mengalami depresi, didapat 27 orang ibu (45,76\%) responden yang tidak mendapat dukungan suami (Fairus and Widiyanti 2014). Hasil analisis menunjukkan bahwa terdapat hubungan antara dukungan suami dengan kejadian depresi pasca melahirkan (Fairus and Widiyanti, 2014). Tingkat fenomena depresi pasca melahirkan yang cukup tinggi tersebut menjadi salah satu latar belakang penelitian ini dilakukan di Lampung tepatnya di Kota Bandar Lampung. Selain itu, pra-riset juga dilakukan melalui pencarian informan yang pernah menjadi pasien di salah satu klinik bersalin di Kota Bandar Lampung. Pemilihan klinik ini didasari oleh tingkat persalinan yang cukup tinggi, sampai akhirnya didapatkan dua informan yang bersedia untuk memberikan pernyataan dalam pra-riset. Ibu DL (29) menjelaskan bahwa komunikasi yang dijalin dengan pasangan atau suami pasca kehadiran anak sangatlah buruk, "kami berdua semakin lama semakin menjauh dan cuek satu sama lain", tuturnya. Sedangkan Ibu OP (29) menuturkan bahwa komunikasi yang terjalin juga kurang baik, ditambah suami sibuk dengan pekerjaan dan jarang menghabiskan waktu dengan istri. Sesuai dengan penelitian terdahulu yang telah menganalisis bahwa terdapat hubungan yang signifikan antara depresi pasca persalinan dan hubungan yang buruk dengan suami. Hal lain menunjukkan keterkaitannya dengan aspek hubungan komunikasi (Romito, 1990). Sehingga pendekatan komunikasi dipandang penting untuk menelaah fenomena ini. Penelitian ini akan mengkaji mengenai pola komunikasi pasangan dalam periode mengalami tekanan (depresi) pasca melahirkan yang dilengkapi dengan penggunakan beberapa aspek dari Relational Turbulalnce Theory sebagai konteks yang menjelaskan mengenai gangguan relasi antar suami-istri pada periode depresi pasca melahirkan.

Pola komunikasi merupakan bentuk sederhana dari keseluruhan proses komunikasi yang menunjukkan kaitan antara satu unsur komunikasi dengan unsur lainnya (Soejanto, 2005). Beberapa pola komunikasi yang dijelaskan oleh (DeVito, 2001) dalam hubungan relasi 
interpersonal pada pasangan diantaranya equality pattern, balance split pattern, unbalanced split pattern, dan monopoly pattern. (1) Pola komunikasi setara (equally pattern), menjelaskan bahwa proses komunikasi terjadi secara timbal balik seimbang, jujur dan terbuka. Peran tiap orang dianggap setara dan bebas dalam mengemukakan pendapat, maupun kepercayaan. Konflik yang terjadi dianggap bukan ancaman, dan hanya dianggap sebagai benturan atas perbedaan nilai dan persepsi yang merupakan bagian dari hubungan jangka panjang. (DeVito 2001). (2) Pola komunikasi seimbang terpisah (balance split pattern), yaitu pola komunikasi yang dimana masing-masing partisipan komunikasi memiliki peran atau ranah dominan yang berbeda namun dengan keterlibatan yang setara. Pembagian peran berdasarkan pola komunikasi ini bersifat fleksibel. Konflik yang terjadi bukan sebagai ancaman, tiap orang tidak dirugikan karena memiliki ranah keunggulannya sendiri-sendiri. (DeVito, 2001). (3) Pola komunikasi tidak seimbang terpisah (unbalanced split pattern), disaat satu individu dianggap lebih ahli dalam sebuah konteks komunikasi timbal balik. Satu orang yang mendominasi dianggap lebih sering memegang kontrol dalam pengambilan keputusan dan jarang menerima pendapat dari orang lain, kecuali untuk sekedar meyakinkan pihak lain atas kehebatan argumennya. Sebaliknya, individu lain bergantung pada pihak yang mendominasi dalam mengambil keputusan. (DeVito, 2001). (4) Pola komunikasi monopoli (monopoly pattern), terdapat satu orang yang berperan sebagai penguasa dengan karakter memberi perintah dibandingkan menjalin komunikasi timbal balik. Individu yang memegan kendali ini tidak akan meminta pendapat dan merasa memeliki wewenang atas pengambilan keputusan. Pola ini jarang memicu pertikaian karena komunikasi hanya didominasi satu orang. Pihak yang mengontrol meraih kepuasan akan perannya dengan menyuruh, memimpin dan menjaga pihak lain, sedangkan pihak lain itu mendapatkan kepuasan melalui pemenuhan kebutuhannya dan lepasnya tanggung jawab atas konsekuensi yang mungkin timbul karena keputusan tersebut bukan keputusannya (DeVito, 2001).

Sedangkan, Relational Turbulance Theory mencoba menggambarkan bagaimana seseorang berpikir, merasakan, dan berkomunikasi ketika keadaan berubah dalam hubungan mereka (L. K. Knobloch et al., 2018). Relational Turbulance Model merupakan teori yang menitikberatkan pada masa transisi dalam sebuah hubungan yang merupakan momen dimana komunikasi interpersonal menjadi penting dalam menilai keadaan hubungan relasi. Transisi merupakan situasi yang menentukan sekaligus membutuhkan redefinisi peran (Leanne K. Knobloch, Nichols, and Martindale-Adams, 2015). Secara lebih spesifik, transisi menimbulkan perubahan yang menyangkut pada rekonstruksi dan reintegrasi identitas, peran, hubungan, atau perilaku, yang kemungkinan mewajibkan individu untuk merubah perilaku maupun cara mereka mengartikan diri maupun hubungan mereka (D. Solomon, Weber, and Steuber, 2010). Seperti halnya yang ditemukan dalam fenomena depresi pasca melahirkan, bahwa terdapat perubahan terhadap kondisi pasangan, baik dalam lingkup komunikasi, peran, dan sebagainya karena adanya tanggung jawab baru yang menuntut penyesuaian diri. Transisi secara erat melibatkan tingkat ketidakstabilan, karena orang mengubah pikiran dan tindakan mereka untuk mencari yang lebih cocok dengan keadaan mereka baru (D. H. Solomon and Theiss, 2011). Solomon menggunakan sebutan 'turbulensi' sebagai tanda dari pengalaman yang penuh guncangan yang mungkin terjadi dalam hubungan sebagai reaksi terhadap transisi (Brisini, Solomon, and Nussbaum, 2017).

Relational Turbulance Theory didasari oleh teori tentang ketidakpastian dari bidang komunikasi antarpribadi (A. Suter and M. Seurer, 2018) dan saling ketergantungan dari psikologi sosial (A. Suter and M. Seurer, 2018), yang mengasumsikan bahwa perubahan dalam lingkungan relasional memicu ketidakpastian hubungan dan mengganggu proses saling ketergantungan. Sehingga menimbulkan efek bias pada penilaian seseorang, reaksi emosional, dan perilaku komunikasi dalam menanggapi kondisi tertentu (L. K. Knobloch et al. 2018). Ketidakpastian relasional merupakan tingkat kepercayaan individu terhadap pemahaman mereka mengenai keterlibatan dalam suatu hubungan. Hal tersebut mencakup pertanyaan mengenai posisi seseorang dalam suatu hubungan (self-uncertainty), pertanyaan mengenai keterlibatan pasangan dalam hubungan (partner-uncertainty), dan pernyataan 
tentang kondisi hubungan itu sendiri (relationship uncertainty) (D. Solomon, Weber, and Steuber, 2010). Relevansi antara ketidakpastian hubungan dengan konteks pasangan dalam masa-masa menghadapi depresi pasca melahirkan dinilai dari menentukan apakah individu dalam hubungan tersebut mengalami pertanyaan tentang keterlibatan satu sama lain. Sejalan dengan memperhatikan mengenai keterlibatan masing-masing individu dalam hubungan, pasangan juga harus mengembangkan pola fungsional saling ketergantungan untuk menunjang aktivitas dan rutinitas sehari-hari (D. H. Solomon and Theiss, 2011). Sikap saling ketergantungan merupakan salah satu bentuk sikap yang menunjukkan seberapa banyak individu membutuhkan dan mempengaruhi individu lain dalam mencapai tujuan sehari-hari (Leanne K. Knobloch, Nichols, and Martindale-Adams 2015). Pengaruh pasangan dapat terwujud dalam dua bentuk: bantuan (facilitate) dan gangguan(interference) dari pasangan (Theiss, Carpenter, and Leustek, 2015). Pengaruh pasangan dalam aktivitas dinilai sebagai bantuan ketika rutinitas yang dijalankan menjadi lebih efektif, sedangkan dianggap sebagai gangguan ketika keterlibatan pasangan mengganggu rutinitas dan membuat kegiatan jadi sulit dilakukan dan diselesaikan (D. Solomon, Weber, and Steuber, 2010).

Berdasarkan paparan fenomena yang didapat dari penelitian terdahulu sudah dijelaskan di atas, penelitian ini akan mengkaji bagaimana aspek-aspek dalam Relational Turbulance Theory dapat diterapkan untuk mengetahui pola komunikasi pasangan yang digunakan oleh pasangan suami-istri saat menghadapi depresi pasca melahirkan. Penelitian ini akan dilakukan secara kualitatif dan teknik pengumpulan data melalui proses wawancara terhadap pasangan suami istri yang berdomisili di Bandar Lampung, yang didapat melalui teknik penentuan sampe yaitu snowball sampling. Tujuan penelitian yaitu untuk mengetahui pola komunikasi pasangan suami-istri yang pernah mengalami tekanan (depresi) pasca melahirkan dengan lokus penelitian di Kota Bandar Lampung. Penelitian ini mengangkat judul "Pola Komunikasi Suami-Istri Dalam Tekanan Pasca Melahirkan di Kota Bandar Lampung".

\section{METODE}

Berdasarkan latar belakang serta tujuan penelitian yang ingin dicapai, penelitian ini menggunakan metode penelitian kualitatif dengan paradigma konstruktivis. Penelitian kualitatif merupakan cara untuk memahami makna individu atau kelompok yang berkaitan dengan masalah sosial atau manusia (Creswell, 2009). Melalui paradigma konstruktivis, individu mencari pemahaman dan mengembangkan makna subjektif yang didapat dari pengalamannya. Bentuk makna ini beragam dan lebih mengarahkan peneliti untuk memperluas kompleksitas pandangan daripada mempersempit makna (Creswell, 2009). Teknik penentuan informan yang dilakukan dalam penelitian ini adalah teknik snowball sampling, yaitu tenik dengan multitahapan. Dimulai dengan menemukan informan-informan kunci yang memiliki karakteristik dan informasi sesuai konteks penelitian yang memungkinan didapatkannya rekomendasi terhadap responden-responden potensial dengan karakteristik yang sesuai guna keperluan penelitian (Nurdiani, 2014). Teknik pengumpulan data yang digunakan adalah wawancara terhadap empat pasangan suami istri selaku informan utama dan satu informan ahli sebagai konfirmasi data. Selanjutnya, peneliti akan menggunakan teknik analisis dengan tiga tahap, yaitu reduksi data (data reduction), penyajian data (data display), dan penyimpulan dan verifikasi data (conclusion drawing/verification) (Sugiyono, 2007). Tahap awal reduksi data, yaitu pengurangan terhadap data yang dianggap tidak relevan, maupun penambahan pada data yang dirasa masih kurang. Tahap kedua, penyajian data, yaitu pengelompokkan data berdasarkan sebuah kategori sehingga memudahkan proses analisis data, dan terakhir menyimpulkan data didukung dengan bukti-bukti yang valid menurut penelitian terdahulu dan pendapat dari informan ahli. Sedangkan untuk menguji keabsahan data, peneliti menggunakan triangulasi sumber, dengan cara melakukan wawancara dengan sumber berbeda yaitu psikolog klinis selaku informan ahli dalam penelitian ini yang bertujuan untuk menguji kredibilitas data. 


\section{HASIL DAN PEMBAHASAN}

Hasil dan pembahasan yang didapatkan dalam penelitian ini berkenaan dengan tiga aspek utama yang dinilai dapat dijadikan poin analisis dalam menjelaskan keterkaitannya dalam mengetahui pola komunikasi pasangan suami-istri dalam menghadapi depresi pasca melahirkan. Ketiga aspek yang akan dibahas terkait dengan upaya pasangan dalam menghadapi periode depresi pasca melahirkan meliputi; proses transisi, dukungan dan hambatan komunikasi (meliputi ketidakpastian hubungan dan sikap saling ketergantungan) serta manajemen konflik.

\section{Proses Transisi}

Pada proses transisi yang dialami oleh pasangan suami istri selama mengalami peride depresi pasca melahirkan umumnya dijumpai penurunan kualitas komunikasi yang ditandai oleh berkurangnya intensitas komunikasi serta kurangnya perhatian dari pasangan. Hal ini sesuai dengan penelitian terdahulu mengenai transisi pada pernikahan yang menyebutkan bahwa kurangnya intensitas interaksi yang terjalin antara pasangan berpengaruh terhadap kondisi relasi dan kualitas hubungan pasangan, ia juga menjelaskan bahwa interaksi dengan pasangan selama masa transisi dapat memelihara kesejahteraan fisik dan emosional (Brisini, Solomon, and Nussbaum, 2017). Relasi yang terjalin di antara suami dan istri memberi landasan dan menentukan warna bagi keseluruhan relasi di dalam keluarga, salah satu aspek utama yang menjadi kunci keberhasilan melakukan penyesuaian antar pasangan ada komunikasi (Lestari, 2012). Penurunan kualitas komunikasi pada pasangan ini sebagian besar faktornya disebabkan oleh kelelahan mengurus anak serta kelelahan dalam pekerjaan sehingga kualitas waktu yang dihabiskan untuk pasangan berkurang. Hal berkaitan dengan penelitian yang menyatakan bahwa pada periode depresi pasca melahirkan, istri mengalami gejala-gejala tertentu yang salah satunya adalah kelelahan fisik (Oktiriani, 2017). Berdasarkan hal tersebut, kualitas interaksi dan komunikasi yang sudah menurun akibat adanya proses penyesuaian ini butuh upaya untuk ditingkatkan kembali. Dengan meningkatkan intensitas komunikasi, tingkat keparahan dan upaya menghadapi periode postpartum blues dapat teratasi, karena interaksi menjadi indikator utama dalam keberhasilan periode transisi yang terjadi pada hubungan (Meleis et al., 2000).

Selain meninjau perubahan interaksi, hasil penelitian pada proses transisi juga meunjukan adanya perubahan tingkat kestabilan emosi yang dialami oleh pasangan yang mengalami periode depresi pasca melahirkan, yang seluruhnya terjadi pada pihak istri. Selaras dengan salah satu hasil penelitian yang menyatakan bahwa terjadi perubahan emosi pada istri setelah kelahiran anak terutama saat mengalami depresi pasca melahirkan (Maulida, 2019). Bentuk perubahan emosi ini yang dialami yaitu tingkat sensitifitas yang meningkat pada seluruh pasangan, yang memiliki kesamaan dengan penelitian dari (Roswiyani, 2010) yang menyebutkan bahwa keadaan individu menjadi lebih sensitif termasuk ke dalam gejala dari depresi pasca melahirkan.

Selain itu perubahan emosi yang terjadi dalam bentuk lain adalah menjadi lebih mudah marah yang terjadi pada dua pasangan, mudah marah dan muncul ketakutan yang berlebihan pada satu pasangan. Hal ini sesuai dengan pernyataan bahwa dalam periode depresi pasca melahirkan, istri mengalami gangguan emosional berupa kondisi lebih mudah marah dan menangis. Hal ini dikonfirmasi oleh psikologi ahli yang meyebutkan bahwa perubahan emosi yang terjadi pada ibu pasca melahirkan dinilai sebagai kondisi yang wajar, dikarenakan adanya perubahan besar dalam diri dan keseharian individu tersebut, mulai dari bertambahnya peran, tanggung jawab dan pola aktivitas. Penelitian pada proses transisi juga meghadirkan adanya perubahan pola aktivitas dan kebiasaan pada seluruh pasangan yang mengalami periode depresi pasca melahirkan yang juga sesuai dengan konfirmasi psikolog ahli. Hadirnya 
perubahan pola aktivitas dan kebiasaan ini memaksa mereka untuk berupaya menghadapi proses transisi yang salah satu caranya adalah dengan mengubah perilaku dan kebiasaan agar sesuai dengan keadaan baru mereka. Hal ini berkaitan dengan pemahaman bahwa transisi secara erat melibatkan tingkat ketidakstabilan, karena orang mengubah pikiran dan tindakan mereka untuk mencari yang lebih cocok dengan keadaan baru mereka (D. H. Solomon and Theiss, 2011).

\section{Dukungan dan Hambatan Komunikasi}

Berdasarkan hasil penelitian didapatkan hasil bahwa tiga dari empat ibu postpartum mengalami fase ketidakpastian hubungan. Satu orang merasakan keraguan terhadap keterlibatan pasangannya dalam berperan sebagai suami dan orang tua. Berdasarkan teori turbulansi relasi hal ini disebut dengan partner-uncertainty (ketidakpastian pasangan). Diketahui sebelumnya bahwa partner uncertainty (ketidakpastian pasangan) merupakan salah satu aspek dari ketidakpastian hubungan, yang menjelaskan mengenai pemahaman atas keterlibatan pasangan dalam hubungan relasi (D. Solomon, Weber, and Steuber, 2010). Sementara itu, dua lainnya merasa tidak mampu dan khawatir dalam menjalankan peran seorang ibu untuk anaknya, yang juga termasuk dalam aspek pada relational uncertainty (ketidakpastian hubungan), yaitu self-uncertainty (ketidakpastian diri) yang merupakan pertanyaan mengenai posisi individu dalam suatu hubungan. Relevansi antara ketidakpastian hubungan dengan konteks pasangan dalam masa-masa menghadapi depresi pasca melahirkan dinilai dari menentukan apakah individu dalam hubungan tersebut mengalami pertanyaan tentang keterlibatan satu sama lain (Leanne K. Knobloch, Nichols, and MartindaleAdams, 2015). Hal inilah yang mengakibatkan timbulnya keraguan baik kepada diri mereka sendiri dan kepada pasangan yang memicu adanya turbulensi atau hambatan dalam hubungan relasi. Pernyataan mengenai ketidakpastian relasional mempersulit transisi dalam hubungan romantis dengan memperburuk reaksi terhadap peristiwa atau pengalaman (D. H. Solomon and Theiss, 2011) dianggap sesuai dengan hasil penelitian ini. Berdasarkan konfirmasi dari ahli yang menyebutkan bahwa timbulnya ketidakpastian relasional membuat orang menilai pengalaman mereka dengan sudut pandang yang lebih negatif (D. H. Solomon and Theiss, 2011).

Berdasarkan data penelitian didapatkan hasil bahwa seluruh pasangan menunjukkan sikap positif pada pasangan dalam bentuk memberi afirmasi positif, memberi semangat, dan menjadi pendengar yang baik. Sikap positif dinilai sebagai salah satu bentuk fasilitasi atau bantuan yang merupakan salah satu aspek dari sikap saling ketergantungan yang dihadirkan oleh pasangan guna membuat rutinitas pada periode depresi pasca melahirkan menjadi lebih mudah dijalani (Theiss, Carpenter, and Leustek, 2015). Sikap positif juga termasuk satu dari lima aspek yang diterapkan oleh pasangan agar mencapai komunikasi interpersonal yang efektif (DeVito, 2001). Selain itu, hasil penelitian juga menunjukkan adanya sikap mendukung terhadap pasangan melalui beberapa bentuk perilaku, yaitu turut serta menjaga anak dan berusaha membantu pekerjaan rumah. Sikap mendukung dinilai termasuk sebagai salah satu faktor bantuan dari pasangan yang memudahkan tercapainya tujuan bersama secara efektif, goals dalam hal ini yaitu melakukan penyesuaian peran dalam proses transisi pada periode depresi pasca melahirkan (Theiss, Carpenter, and Leustek, 2015). Dalam upaya mencapai tujuan tersebut, sikap mendukung menjadi salah satu faktor yang menunjang terciptanya komunikasi yang efektif antar pasangan (DeVito, 2001).

Hasil penelitian juga menunjukkan bahwa terdapat beberapa gangguan dari pasangan, yang diantaranya adalah beberapa pasangan kurang sigap menjalankan perannya. Hal ini sesuai dengan pernyaataan yang menyebutkan bahwa sesuatu dianggap sebagai gangguan (interference) ketika timbul pengaruh secara negatif apabila pasangan tidak memainkan perannya (D. H. Solomon and Theiss, 2011). Selain itu, hasil temuan juga menunjukkan bahwa gangguan (interference) lain yang terjadi pada pasangan selama mengalami depresi pasca 
melahirkan adalah kesulitan individu menjalankan peran tanpa keterlibatan pasangan. Bentuk temuan ini terdiri dari kurangnya validasi perasaan, kurangnya perhatian, hadirnya kecemburuan, serta penurunan keberfungsian individu jika pasangan tidak bersamanya. Hal ini juga menjadi salah satu faktor gangguan yang menghambat hubungan relasi antar pasangan, sesuai dengan penelitian terdahulu yang menyebutkan bahwa kurangnya keterlibatan pasangan dapat mengganggu rutinitas dan membuat tindakan mencapai tujuan jadi sulit dilakukan (D. Solomon, Weber, and Steuber, 2010).

Di samping itu, hasil penelitian juga menunjukan bahwa sikap saling ketergantuan yang saling dipengaruhi antar pasangan terwujud dalam dua hal yaitu pasangan dalam perannya sebagai fasilitasi (memberi bantuan dan memudahkan tujuan/proses transisi tercapai secara efektif.) atau berperan sebagai gangguan (ketika pasangan menghalangi pasangannya dalam menjalankan peran barunya sebagai orang tua). Pola saling ketergantungan akan berguna selagi masing-masing individu responsif terhadap kondisi intrapersonal, interperpersonal dan kontekstual untuk kelangsungan hubungan (D. H. Solomon and Theiss, 2011).

Hal ini dikonfirmasi oleh psikolog ahli yang menyatakan bahwa masing-masing individu harus responsif terhdapat perubahan-perubahan yang terjadi pada pasangan, terutama dalam konteks menghadapi depresi pasca melahirkan. Dengan mengetahui dan menyadari kondisi pasangannya maka akan lebih mudah mengatasi dan menghadapi perubahan tersebut. Perbedaan perlakuan sesuai kebutuhan masing-masing pasangan ini bertujuan untuk menunjang proses penyesuaian dan proses adaptasi pada periode pasca melahirkan, yang hasilnya akan meminimalisir dampak negatif pada kelangsungan hubungan. Informan ahli juga berpendapat bahwa peran orang terdekat terutama pasangan, yang memiliki intensitas interaksi yang lebih banyak sangat diharapkan untuk selalu memberikan bantuan demi keefektifan proses penyesuaian selama periode pasca melahirkan tersebut.

\section{Manajemen Konflik}

Berdasarkan penelitian didapatkan hasil bahwa konflik yang ditemui terkait dengan tugas pengasuhan anak. Hal ini sesuai dengan penelitian yang menyebutkan bahwa terdapat kontradiksi antara suami dan istri saat mengalami periode depresi pasca melahirkan yang pada dasarnya disebabkan oleh pembagian kerja, di mana istri lebih banyak mengurus anak (Maulida, 2019). Dijelaskan juga bahwa konflik akan muncul apabila tanggung jawab yang dibebankan kepada salah satu individu lebih banyak sehingga terjadi peningkatan tekanan, sehingga salah satu pihak memandang hubungan mereka kurang seimbang (Leanne $\mathrm{K}$. Knobloch, Nichols, and Martindale-Adams, 2015). Sesuai dengan pendapat yang disampaikan oleh informan ahli bahwa pemicu konflik dan timbulnya depresi pasca melahirkan berasal dari dua sumber, yaitu nurture (lingkungan luar) dan nature (berasal dari individu itu sendiri) yang dalam hal ini contohnya adalah kurangnya asupan dukungan emosional dan bantuan fisik terutama dari pasangan. Selain itu, juga terdapat temuan terhadap bentuk konflik lain yang terjadi pada pasangan dalam periode depresi pasca melahirkan yaitu kurangnya kualitas interaksi antarpasangan dalam bentuk kurang perhatian dari pasangan karena suami bekerja. Hal ini sesuai dengan pernyataan ahli yang menyebutkan bahwa interaksi dapat membantu pasangan dalam mengatasi periode perubahan dan melalui interaksi, makna serta perilaku pasangan dalam menanggapi transisi dapat ditemukan dan diklarifikasi (Brisini, Solomon, and Nussbaum, 2017). Berkurangnya interaksi menghilangkan salah satu aspek utama yang menjadi kunci keberhasilan melakukan penyesuaian antar pasangan selama masa transisi (Lestari, 2012).

Menanggapi hadirnya konflik, bentuk upaya manajemen konflik yang dilakukan menurut hasil penelitian adalah adanya sikap keterbukaan antarpasangan, yang ditandai dengan adanya kompromi, saling mendengarkan dan pengutaraan keluhan. Hal ini sesuai dengan upaya terbentuknya komunikasi yang efektif antar suami dan istri, di mana keterbukaan menjadi salah satu dari lima aspek keefektifan komunikasi (DeVito, 2001). Sesuai 
dengan pendapat psikolog ahli yang juga menyatakan bahwa, keterbukaan antar pasangan mengenai kesadaran akan kondisinya (Depresi Pasca Melahirkan) sangat penting untuk diperhatikan, dengan mengutarakan keadaanya pada pasangan, akan lebih mudah mengetahui langkah yang harus diambil dalam upaya mengatasinya. Menurut beliau, hal ini bertujuan untuk menjaga fungsionalitas peran individu dalam pasangan agar tidak menimbulkan dampak berkepanjangan. Penelitian juga mendapatkan hasil bahwa manajemen konflik yang diterapkan oleh pasangan yang mengalami depresi pasca melahirkan yaitu melalui komunikasi. Hal ini sesuai dengan pernyataan ahli yang menyebutkan bahwa komunikasi dapat membantu pasangan dalam mengatasi periode perubahan dan melalui interaksi, makna serta perilaku pasangan dalam menanggapi transisi dapat ditemukan dan diklarifikasi (Brisini, Solomon, and Nussbaum, 2017). Sehingga, berdasarkan penjelasan di atas, penggunaan strategi penyelesaian konflik konstruktif (keterbukaan, komunikasi dan kompromi) merupakan upaya yang efektif dalam membantu kelangsungan hubungan relasi selama periode depresi pasca melahirkan (Gottman and Krokoff, 1989).

Sehingga, didapatkan hasil mengenai pola komunikasi yang digunakan oleh pasangan suami istri selama menghadapi periode depresi pasca melahirkan di Bandar Lampung berdasarkan paparan dan analisis dari aspek-aspek di atas adalah pola komunikasi seimbang terpisah (balanced split pattern). Pola komunikasi yang digunakan dalam periode depresi pasca melahirkan ini dilatar belakangi oleh adanya pembagian peran yang berbeda pada masing-masing individu dalam relasi, dalam hal ini yaitu suami dan istri, di mana sang istri memiliki peran mengasuh dan mengurus anak di rumah sedangkan sang suami menjalankan peran dengan mencari nafkah melalui bekerja guna memenuhi kebutuhan keluarga. Pembagian peran ini tetap memperhatikan kesetaraan antar kedua belah pihak dan tetap bersifat fleksibel, ditandai dengan sang suami yang kerap membantu pekerjaan rumah untuk meringankan beban sang istri. Selain itu masing-masing idividu saling memberikan dan menunjukkan sikap mendukung dalam bentuk ikut serta menjaga serta mengurus anak serta memberikan sikap positif dengan memberi pujian pada pasangan, menunjukkan afirmasi positif serta selalu siap sedia menjadi pendengar yang baik atas keluh kesah yang disampaikan pasangan. Dijelaskan bahwa pada pola komunikasi seimbang terpisah ini, masing-masing pasangan tetap memiliki tingkat keterlibatan yang setara pada hubungan relasi. Pembagian peran yang berbeda didasarkan pada kemampuan dan keahlian masingmasing individu, sehingga tiap partisipan komunikasi tetap memiliki daerah dominannya sendiri, namun sesuai dengan pendapat dari Devito yang menyebutkan bahwa pembagian peran pada pola komunikasi ini bersifat fleksibel sesuai dengan keadaan dan kesepakatan masing-masing individu dalam hubungan relasi (DeVito, 2001).

Bentuk konflik yang menjadi temuan dalam penelitian ini yaitu mengenai kurangnya interaksi yang terjadi antar pasangan dan pembagian tugas mengurus anak. Perihal pembagian tugas mengurus anak, menurut hasil penelitian didapat bahwa masing-masing individu merasa kesulitan dalam membagi waktu untuk menjaga anak, hal ini disebabkan oleh kurangnya waktu tidur dan kelelahan atas aktivitas lain yang dilakukan seperti bekerja dan mengurus pekerjaan rumah, sehingga terkadang terdapat ketimpangan peran pada hubungan relasi. Selain itu mengenai perbedaan cara mengurus anak yang juga menjadi alasan pemicu terjadinya konflik karena suami dan istri berasal dari latar belakang keluarga yang berbeda. Berkurangnya intensitas komunikasi dan kualitas waktu bersama dinilai berkaitan dengan terjadinya proses transisi pada periode pasca melahirkan tersebut dan dianggap cukup wajar untuk dialami oleh pasangan suami-istri sehingga konflik ini bukanlah menjadi ancaman bagi pasangan. Namun, tetap dianggap penting untuk menyadari keadaan pasangan dan menjalin keterbukaan komunikasi antarpasangan demi mengurangi peluang terjadinya depresi pasca melahirkan atau mengurang tingkat keparahannya, sehingga masing-masing individu dalam hubungan tetap bisa menjalankan keberfungsiannya dalam hubungan relasi secara maksimal. Penggunaan strategi konstruktif oleh keempat pasangan sebagai strategi manajemen konflik menekankan pada keterbukaan komunikasi dalam bentuk menyampaikan keluhan dan permasalahan yang dihadapi serta tetap mengedepankan kompromi atau negosiasi dengan 
pasangan, sehingga konflik yang terjadi dapat terselesaikan dengan keputusan yang diambil dan dikomunikasikan dari kedua belah pihak yaitu suami dan istri.

\section{SIMPULAN DAN SARAN}

Pola komunikasi pasangan yang digunakan dalam menghadapi tekanan (depresi) pasca melahirkan di Bandar Lampung yaitu pola komunikasi seimbang terpisah (balance split pattern), yang ditandai oleh masing-masing individu dalam pasangan membagi tanggung jawab yang setara pada peran yang berbeda, serta didukung dengan adanya sikap positif seperti memberi afirmasi positif, memberi semangat, dan menjadi pendengar yang baik; adanya sikap mendukung seperti turut serta menjaga anak dan berusaha membantu pekerjaan rumah; dan keterbukaan yang terjalin antarpasangan dalam bentuk kompromi, saling mendengarkan dan penyampaian keluhan.

Dalam pola komunikasi seimbang terpisah, seluruh informan mengalami gangguan dalam bentuk pasangan kurang sigap dan kesulitan individu menjalankan peran tanpa keterlibatan pasangan; serta terdapat bantuan pasangan dalam bentuk hadirnya sikap positif dan sikap mendukung, sementara sebagian mengalami ketidakpastian hubungan dalam bentuk ketidakpastian pada peran diri sendiri (self-uncertainty) dan ketidakpastian pada peran pasangan (partner-uncertainty). Pendekatan dalam strategi manajemen konflik antarpasangan yang didapatkan dalam penelitian ini adalah strategi konstruktif melalui terciptanya komunikasi yang terbuka dan kompromi/ negosiasi antarpasangan. Konflik terkait dengan tugas pengasuhan anak (pembagian tugas dan perbedaan cara mengurus anak) dan kurangnya kualitas interaksi (suami bekerja dan fokus perhatian pada anak) menjadi temuan dalam penelitian ini.

Berdasarkan hasil yang didapat dalam penelitian ini, beberapa saran yang dapat diberikan bagi pasangan suami istri yang sedang menghadapi periode pasca melahirkan terutama yang mengalami peristiwa depresi diharapkan dapat meningkatkan intensitas komunikasi dan interaksi dalam bentuk pemberian perhatian dan bantuan fisik untuk mengurangi turbulensi dalam hubungan relasi selama masa transisi. Masing-masing individu dalam hubungan pasangan juga diharapkan menjaga keterbukaan dan negosiasi dalam menanggapi perubahan dan penyesuaian kondisi selama periode depresi pasca melahirkan. Serta, baik pihak istri maupun suami diharapkan untuk dapat mengoptimalkan tanggung jawab dan perannya dalam hubungan relasi agar tidak terjadi ketimpangan di salah satu pihak.

\section{DAFTAR PUSTAKA}

A. Suter, E., \& M. Seurer, L. (2018). Engaging Theories in Family Communication (Vol 2). In Routledge.

Atmadibrata. (2005). Punya bayi kok, malah sedih. Femina, 32.

Brisini, K. S. C., Solomon, D. H., \& Nussbaum, J. (2017). Transitions in marriage: Types, turbulence, and transition processing activities. Journal of Social and Personal Relationships, 35(6), 831-853. https://doi.org/10.1177/0265407517699283

Creswell, J. W. (2009). Research Design: Qualitative, Quantitative and Mixed Approaches (3rd Edition). In Research Design: Qualitative, Quantitative, and Mixed Methods Approaches. https://doi.org/10.2307/1523157

DeVito, J. (2001). Interpersonal Communication. Professional Books.

Dewi, N. R., \& Sudhana, H. (2013). Hubungan Antara Komunikasi Interpersonal Pasutri dengan Keharmonisan dalam Pernikahan. Jurnal Psikologi Udayana. https://doi.org/10.24843/jpu.2013.v01.i01.p03

Fairus, M., \& Widiyanti, S. (2014). Hubungan dukungan suami dengan kejadian depresi postpartum pada ibu nifas. Jurnal Kesehatan, VII(1), 11-18.

Gottman, J. M., \& Krokoff, L. J. (1989). Marital Interaction and Satisfaction: A Longitudinal 
View. Journal of Consulting and Clinical Psychology, 57(1), 47-52. https://doi.org/10.1037//0022-006x.57.1.47

Knobloch, L. K., Solomon, D. H., Theiss, J. A., \& McLaren, R. M. (2018). Relational Turbulence Theory: Understanding Family Communication During Times of Change. In Engaging Theories in Family Communication. (Second Edi). Routledge.

Knobloch, Leanne K., Nichols, L. O., \& Martindale-Adams, J. (2015). Applying relational turbulence theory to adult caregiving relationships. Gerontologist, 60(4), 598-606. https://doi.org/10.1093/geront/gnz090

Lestari, S. (2012). Psikologi Keluarga. Kencana Prenada Media Group.

Liliweri, A. (2015). Komunikasi Antarpersonal. In Kencana Prenadamedia Group.

Maulida, S. (2019). Komunikasi Interpersonal Pasangan Suami Istri Pasca Kelahiran Anak Pertama.

Meleis, Ibrahim, Sawyer, L. M., Im E. O., Messias, and Schumacher K. (2000). "Experiencing Transitions: An Emerging Middle-Range Theory." Advances in Nursing Science 23 (1): 12-28. https://doi.org/10.1097/00012272-200009000-00006.

Muladsih, O. R., Muflikhati, I., \& Herawati, T. (2011). Pola Komunikasi, Pengambilan Keputusan, dan Kesejahteraan Keluarga Jarak Jauh: Kasus Keluarga Mahasiswa Pascasarjana. Jurnal Klmu Keluarga Dan Konsumen. https://doi.org/10.24156/jikk.2011.4.2.121

Nurdiani, N. (2014). Teknik Sampling Snowball dalam Penelitian Lapangan. ComTech: Computer, Mathematics and Engineering Applications, 5(2), 1110. https://doi.org/10.21512/comtech.v5i2.2427

Oktiriani, I. (2017). Perilaku Baby Blues Syndrome Pada Ibu Pasca Melahirkan Di Kelurahan Sekaran Kecamatan Gunungpati Kabupaten Semarang. Universitas Negeri Semarang.

Romito, P. (1990). Postpartum Depression and the Experience of Motherhood. Acta $\begin{array}{lllll}\text { Obstetricia et Gynecologica } & \text { Scandinavica. }\end{array}$ https://doi.org/10.3109/00016349009156507.

Roswiyani. (2010). Postpartum depression. Journal of Clinical Psychiatry, 65(9), 1235. https://doi.org/10.4088/JCP.v65n0912

Soejanto, A. (2005). Psikologi Komunikasi. Bandung: PT Remaja Rosdakarya.

Solomon, D. H., \& Theiss, J. A. (2011). Relational turbulence: What doesn't kill us makes us stronger. In The dark side of close relationships II (In W. R. C, pp. 197-216). Routledge.

Solomon, D., Weber, K., \& Steuber, K. (2010). Turbulance in Relational Transition. In S. W. Smith \& S. R. Wilson (Eds.), New Direction in Interpersonal Communication Research (pp. 115-130). SAGE Publications, inc.

Sugiyono. (2007). Metodologi Penelitian Pendidikan. Alfabeta.

Theiss, J. A., Carpenter, A. M., \& Leustek, J. (2015). Partner Facilitation and Partner Interference in Individuals' Weight Loss Goals. Qualitative Health Research, 26(10), 1318-1330. https://doi.org/10.1177/1049732315583980

Yusari, \& Risneni. (2016). Asuhan Kebidanan Nifas dan Menyusui. In Trans Info Media. 